\title{
Briefly
}

Bisphenol A bans unjustified: There is no evidence that governments need to limit or ban the use of bisphenol A (BPA) in food packaging, such as baby bottles and cans, according to an international scientific panel convened by the World Health Organization and the Food and Agriculture Organization of the United Nations. The panel of more than 30 experts said its review indicates that "BPA is not accumulated in the body and is rapidly eliminated through urine" (www.who.int/foodsafety/chem /chemicals/bisphenol_release/en/index .html). "A few recent experimental and epidemiological studies found associations between low BPA exposure levels and some adverse health outcomes. The meeting concluded that, at this stage, it is difficult to interpret the relevance of these studies in the light of current knowledge of this compound. Until these associations can be confirmed, initiation of public health measures would be premature." - Wayne Kondro, CMAJ

Calorie costs: The United States Food and Drug Administration estimates that restaurant chains, grocery and convenience stores, and vending machine operators will have to spend about 15 million hours and roughly US\$29 million to comply with new regulations that require them to disclose calorie content information about food items being offered for sale to consumers (http: //edocket.access.gpo.gov/2010/pdf/2010 -28014.pdf). The FDA estimates that it will take roughly four hours of analysis to determine how many calories are in an individual food item. The menu labelling requirements are part of US President's Barack Obama's health care overhaul. - Wayne Kondro, CMAJ

Fewer children with asthma: The prevalence of asthma among Canadian children aged two to seven has declined to its lowest level in a decade, as has the prevalence of ear infections, according to a study by Statistics Canada. The study, Recent trends in upper respiratory infections, ear infections and asthma among young Canadian children, surmises that the decline in asthma rates are attributable to a number of environmental factors: "changes in the population structure; changes in diagnostic practices; decreases in the prevalence of respiratory allergies; improvements in air quality; changes in hygiene practices (particularly, in child care settings); and reductions in children's exposure to cigarette smoke at home" (www.statcan.gc.ca/pub/82-003 -x/2010004/article/11364-eng.pdf). The study also found that "from 1994/1995 to $2008 / 2009$, the prevalence of upper respiratory infections among children aged 2 to 3 remained constant or declined in most regions of Canada, but rose significantly in Quebec." Wayne Kondro, CMAJ

\section{Pharmacovigilance recommenda-} tions: Health Canada must "be given the legislative authority to impose penalties for failure to complete postmarket safety studies by the required deadline," a discussion paper commissioned by the Health Council of Canada says. The paper, Keeping an Eye on Prescription Drugs: Active Monitoring Systems for Drug Safety and Effectiveness in Canada and Internationally, also recommends that Health Canada develop a protocol for developing and disseminating drug safety messages; that adequate public funding of drug safety and effectiveness research be provided; that drug safety information be publicly released and that "all postmarket research that Health Canada requires from companies, or that is publicly commissioned, should be registered prior to commencement, avoid conflict of interest, and be subject to guidance documents to ensure a rigorous methodology is followed" (www .healthcouncilcanada.ca/docs/rpts/2010/ DSE/DSE_E_FINAL_Nov17.pdf). Wayne Kondro, $C M A J$
Fighting antibiotic resistance: Infectious disease experts are calling on physicians, public health officials and policy-makers to curb the rampant misuse of antibiotics that can lead to increased drug resistance. "Antibiotic resistance is one of the greatest threats to public health in the world," said Dr. James Hughes, president of the Infectious Diseases Society of America, in a news release (www.idsociety.org /Content.aspx?id=17193). "We are already seeing infections resistant to nearly every drug in our arsenal." The society has issued recommendations for a multisector approach to the problem, including such strategies as: educating patients and health care providers on appropriate antibiotic use; stopping the nonjudicious use of antibiotics in animals on farms; passing appropriate legislation; and promoting the research and development of new antibiotics. Earlier in 2010, the society called for a global commitment to develop 10 new antibiotics by 2020. "From appropriately using the antibiotics we have today to promoting the development of new ones, we all have important parts to play in overcoming this serious public health threat," said Hughes. - Lauren Vogel, CMAJ

Same day hip surgery: The United Kingdom's National Institute for Health and Clinical Excellence has issued a draft clinical practice guideline for consultation that recommends that the National Health Service in England, Wales and Scotland offer surgery to all people admitted to hospital with a broken hip "on the day of, or the day after, admission" so as to avoid complications. The guidance also urges that "correctable" comorbidities be treated immediately to ensure "that surgery is not delayed by: anaemia; anticoagulation; volume depletion; electrolyte imbalance; uncontrolled diabetes; uncontrolled heart failure; correctable cardiac arrhyth- 
mia or ischaemia; acute chest infection; or exacerbation of chronic chest conditions" (www.nice.org.uk/nicemedia /live/11968/51532/51532.pdf). The institute will conduct a year of consultations on the proposed guideline. - Wayne Kondro, CMAJ

Flu burden: More than 15000 Canadians were admitted to hospital for treatment of pandemic (H1N1) 2009 last year - some 6500 more cases than first tallied - according to recent study of hospital data by the Canadian Institute for Health Information (CIHI). "While there have been suggestions the response may have been exaggerated, our study shows, in fact, the impact of the virus on hospitals was significant and much higher than originally estimated," Jeremy Veillard, CIHI Vice President of Research and Analysis , said in a news release. "The good news is that Canada's acute care facilities were able to weather the storm" (www.cihi.ca /CIHI-ext-portal/internet/en/Document /types+of+care/hospital+care/acute+care /RELEASE_23NOV10). The study, The Impact of the H1N1 Pandemic on Canadian Hospitals, reveals that the virus accounted for $3.4 \%$ of all hospitalizations at its peak, outnumbering hospitalizations for common conditions, such as heart attacks $(2.5 \%)$ and strokes $(1.6 \%)$, over the same period (http://secure.cihi .ca/cihiweb/products/H1N1_AIB_final _EN.pdf). During the second wave of the virus, some 10000 more flu patients were hospitalized than in a typical year. In Ontario alone, about one in four emergency department visits during October and November of 2009 were for patients with flu-like symptoms, compared to one in seven in previous years. Hospitals accommodated the influx by moving patients from intensive care units to regular wards with additional monitoring, cancelling elective surgeries and calling in extra staff. The virus cost hospitals close to $\$ 200$ million, \$128 million of which was spent over the five busiest weeks of the pandemic. — Lauren Vogel, CMAJ

That's the way the cookie crumbles: The 14-member executive board of Alberta Health Services has dismissed President and Chief Executive Officer
Stephen Duckett after a brouhaha erupted when he dusted off reporter's inquiries about the province's hospital overcrowding crisis on the grounds that he was too busy "eating my cookie" (www.youtube.com/watch?v=5DxeCK 5Ne_Q). Premier Ed Stelmach labelled the comments "offensive" and penned a blog admonishing the "theatrics" (http://alberta.ca/blog/home.cfm/2010 /11/21/Premiers-Statement-Emergency -Rooms). Although Duckett subsequently apologized, the executive board said in a press release that the time had come to "move on" (www.albertahealth services.ca/3191.asp). Board Chair Ken Hughes indicated the board had little political option, telling reporters that Duckett's leadership was "compromised by perceptions, public and others." Duckett is eligible for a severance package of a year's pay plus $15 \%$ (a projected $\$ 680$ 000), plus moving expenses. The economist from Australia became CEO in March 2009 and earned $\$ 744000$ in salary and bonuses in fiscal 2009/10. He was hired to oversee a radical restructuring of the Alberta health care system, in which the province dissolved its regional health authority system and created the "super-board" Alberta Health Services (www.cmaj.ca/cgi/doi/10.1503/cmaj.10 9-3165). — Wayne Kondro, CMAJ

Tide turned on AIDS epidemic: The AIDS epidemic is beginning to change course as both the number of people newly infected with HIV and the number of AIDS-related deaths continue to decline, according a recent report by the Joint United Nations Programme on HIV/AIDS (UNAIDS). Data from the 2010 UNAIDS Report on the global AIDS epidemic shows new HIV infections have fallen by nearly $20 \%$ in the last 10 years, while AIDSrelated deaths are down by almost $20 \%$ in the last five years (www.unaids .org/documents/20101123_GlobalReport _em.pdf). Some 1.8 million people died from AIDS-related illnesses in 2009, nearly one-fifth lower than the 2.1 million people who died in 2004 . At the end of 2009, 33.3 million people were estimated to be living with HIV, up slightly from 32.8 million in 2008. The report attributed this increase to people living longer as access to antiretroviral therapy improves. "We are breaking the trajectory of the AIDS epidemic with bold actions and smart choices," said executive director of UNAIDS Michel Sidibé, in a news release. "Investments in the AIDS response are paying off, but gains are fragile — the challenge now is how we can all work to accelerate progress" (www.unaids .org/documents/20101123_PR_Global Report_en.pdf). - Lauren Vogel, CMAJ

Lead in toys: Health Minister Leona Aglukkaq has unveiled amendments to the Hazardous Products Act that limit the lead content of children's toys, baby bottle nipples, soothers, bibs, drinking straws, musical instrument mouthpieces, sports mouthpieces, consumer paints and other surface coating materials, such as spray paints and primers (www.hc-sc.gc.ca/ahc-asc/media/nr-cp /_2010/2010_203fs-eng.php). The new regulations limit the lead content of "accessible parts of certain consumer products to $90 \mathrm{mg} / \mathrm{kg}$ total lead $(0.009 \%)$. Consumer paints and surface materials had been allowed to have total lead levels of $600 \mathrm{mg} / \mathrm{kg}$. "As a Mom, I'm proud that our new, tough regulations will make Canada a world leader in strict lead reduction in consumer products, especially toys," Aglukkaq said in a press release (www.hc-sc.gc.ca /ahc-asc/media/nr-cp/_2010/2010_203 -eng.php). — Wayne Kondro, CMAJ

Squires Award: Toronto, Ontario, internist Dr. David N. Juurlink and coauthors Tara Gomes, Dr. Dennis T. Ko, Dr. Paul E. Szmitko, Peter C. Austin, Dr. Jack V. Tu, Dr. David A. Henry, Alex Kopp, and Muhammad M. Mamdani have been named recipients of the 2009 Bruce Squires Award from CMAJ. In selecting the study, A рориlation-based study of the drug interaction between proton pump inhibitors and clopidogrel (www.cmaj.ca/cgi/doi /10.1503/cmaj.082001), as the winning paper, "we considered the study's originality, potential to impact practice as well as its methodological rigour," says CMAJ Editor-in-Chief Dr. Paul Hébert. "This paper has had significant impact, 
spurring research into the interaction between proton pump inhibitors and clopidogrel." The Squires Award honours Editor Emeritus Dr. Bruce Squires, who served in various capacities at CMAJ from 1984 to 1996 , including editor-in-chief for seven years. Wayne Kondro, CMAJ

Fee-for-service payment outdated: The Ontario government should consider scrapping fee-for-service payment models for physicians in favour of "blended payment approaches with components of capitation, FFS [Feefor-service] and bonus payments," according to a report from the independent health policy think tank, The Change Foundation. Such blended approaches strengthen physician "accountability for delivering evidencebased care, their uptake of new technologies, and integration with other health professionals," says the report, Tools for Change: Funding Incentives and Levers for Integrating Patient Care in Ontario (www.changefoundation.ca /docs/ToolsForChange.pdf). Other recommendations include: "Use funding mechanisms to support strategic priorities; move beyond provider-based funding models; include primary care in system planning; use non-financial incentives to appeal to excellence; build a culture of quality; make accountability and performance reporting play a bigger role; and maximize good features and remove perverse incentives, apply continuous improvement to funding reform." - Wayne Kondro, CMAJ

US diabetes toll: Roughly $52 \%$ of adult Americans are projected to have diabetes or prediabetes by 2020 , a new report says. The $12 \%$ increase is projected to cost the health care system US\$3.4 trillion over the next decade, according to the report, The United States of Diabetes: Challenges and Opportunities in the Decade Ahead, from the Minnesota-based UnitedHealth Group's Center for Health Reform \& Modernization (www.unitedhealth group.com/hrm/UNH_WorkingPaper5 .pdf). The report projects the annual cost of combatting diabetes will be US $\$ 500$ billion by 2020 , as compared with
US\$194 billion currently. It draws a strong link between diabetes and "unprecedented levels" of obesity. "Dietary change, moderate-intensity exercise, and modest weight loss" would mitigate the risks of developing the disease. It also urges the use of federal screening guidelines to detect prediabetes. The report also says that if programs to prevent and control diabetes were adopted nationally, cost savings to the medical system could reach US\$250 billion. — David Yin, Ottawa, Ont.

Q fever report: The government of the Netherlands responded too slowly the outbreak of the goat and sheep disease, $Q$ fever, that infected 2354 people in 2009, killing six, according to an expert panel struck to assess the crisis. The report, published in Dutch, (www.qkoort sinnederland.nl/uploadedFiles/205.pdf), says that government ministries failed to adequately inform people of the risks of developing $\mathrm{Q}$ fever and the measures that were needed to prevent its spread, according to Dutchnews.nl (www.dutch news.nl/news/archives/2010/11/q_fever _report_criticises_gove.php). Q fever, which is caused by the Coxiella burnetii bacteria, can spread to humans through contact with the milk, urine, feces, vaginal mucus or semen of infected animals. The Dutch government slaughtered over 50000 goats on 55 of the country's goat farms in 2009 in a bid to contain the spread of the disease. - Wayne Kondro, CMAJ

Product alerts: Health Canada has issued foreign product alerts advising Canadians not to purchase 13 different sexual enhancement pills or weightloss supplements after reviews by foreign regulators found that the drugs contained such unauthorized substances as hydroxythiohomosildenafil, didesmethyl sibutramine, tadalafil, sildenafil, sulfoaildenafil, phenolphthalein and sibutramine and minoxidil. Although the products were not reviewed by Health Canada, the alerts were issued based on risk communications provided by foreign regulators, writes David Thomas, media relations officer for Health Canada in an email. The department "has numerous bilateral and multinational networks with others countries health departments/ regulatory agencies. There is a long (and ever growing) list of counterparts with which we have signed confidentiality arrangements (or related enabling mechanisms such as memorandum of understanding or mutual recognition agreements) to share nonpublic information (including the China State Food and Drug Administration, the United States Food and Drug Administration and the New Zealand Medicines and Medical Devices Safety Authority). These inform us of foreign product alerts and possible dangers involving drugs and other health products," writes Thomas. But the drugs can still make their way into Canada through online purchases, or be brought into the country by travellers, Health Canada's website warns. The products included MasXtreme, Tonic 66, and TimeOut (http://hc-sc .gc.ca/ahc-asc/media/advisories-avis/_fpa -ape_2010/index-eng.php\#nov). David Yin, Ottawa, Ont.

Refugee health: A group of 169 physicians and other health care providers have penned a letter to Parliamentarians urging them to vote against Bill C49, the Preventing Human Smugglers from Abusing Canada's Immigration System Act. The bill gives the federal government the authority to imprison those who enter Canada via humansmuggling ships for one year and deny them from applying for permanent residency status for five years. The health care workers write that prolonged detention can damage refugees' mental health and make them incapable of integration into Canadian society. They also write in their letter that without permanent residency status, refugees live "under a constant and real threat of deportation" that damages their ability to live normal lives. "As health care workers familiar with refugee populations, we feel strongly Bill C-49 will further victimize those that have already endured suffering." — William Burr, Ottawa, Ont.

Meningitis vaccine: A low-cost meningitis vaccine was rolled out in Burkina Faso as part of a campaign that the World Health Organization 
(WHO) hopes will eventually eradicate the disease within the 25 countries in sub-Saharan African that have been collectively tagged the "meningitis belt." The MenAfriVac vaccine, which was developed by a publicprivate partnership between the WHO, the nonprofit organization PATH and the Bill and Melinda Gates Foundation, is priced at under US $\$ .50$ per dose. WHO Director-General Dr. Margaret Chan said in a press release that "in fewer than 10 years, we have overcome obstacles that have in the past seemed insurmountable. With a onetime investment to vaccinate populations in all countries of the meningitis belt, nearly 150000 young lives could be saved by 2015, and epidemic meningitis could become a thing of the past. This is within reach. We must not fail" (http://www.who.int/media centre/news/releases/2010/meningitis _20101206/en/index.html). — William Burr, Ottawa, Ont.

Ethics review: United States President Barack Obama has asked his Presidential Commission for the Study of Bioethical Issues to review whether the country has adequate protections for participants in scientific research. In a letter to Chair and University of Pennsylvania President Amy Gutmann, Obama also asked the commission to conduct a "fact-finding investigation" into whether US offi- cials deliberately infected Guatemalan citizens with sexually transmitted diseases during the 1940s (www.whitehouse .gov/the-press-office/2010/11/24/presid ential-memorandum-review-human-sub jects-protection). The letter requests that Gutmann "convene a panel to conduct, beginning in January 2011, a thorough review of human subjects protection to determine if Federal regulations and international standards adequately guard the health and well-being of participants in scientific studies supported by the Federal Government." The panel is asked to report within nine months. Wayne Kondro, CMAJ

CMAJ 2011.DOI:10.1503/cmaj.109-3753 